\title{
MALARIA VECTORS IN THE BRAZILIAN AMAZON: Anopheles OF THE SUBGENUS Nyssorhynchus (1)
}

\author{
Wanderli Pedro TADEI(2) \& Bedsy DUTARY THATCHER(3)
}

\begin{abstract}
SUMMARY
Various species of Anopheles (Nyssorhynchus) were studied in the Amazon with the objective of determining their importance as malaria vectors. Of the 33 known Anopheles species occurring in the Amazon, only 9 were found to be infected with Plasmodium. The different species of this subgenus varied both in diversity and density in the collection areas. The populations showed a tendency towards lower density and diversity in virgin forest than in areas modified by human intervention.

The principal vector, An. darlingi, is anthropophilic with a continuous activity cycle lasting the entire night but peaking at sunset and sunrise. These species (Nyssorhynchus) are peridomiciliary, entering houses to feed on blood and immediately leaving to settle on nearby vegetation.

Anopheles nuneztovari proved to be zoophilic, crepuscular and peridomiciliary. These habits may change depending on a series of external factors, especially those related to human activity.

There is a possibility that sibling species exist in the study area and they are being studied with reference to An. darlingi, An. albitarsis and An. nuneztovari. The present results do not suggest the existence of subpopulations of An. darlingi in the Brazilian Amazon.
\end{abstract}

KEYWORDS: Malaria vectors; Anopheles; Plasmodium; Amazon

\section{INTRODUCTION}

The Instituto Nacional de Pesquisas da Amazonia (INPA) has been studying the anophelines of the Brazilian Amazon region and their behavior over the past few decades. The objectives have been to determine appropriate methods of control for the region, revise the recommendations and suggest how these could be adapted or implemented within the programs of malaria control. Some $99 \%$ of all Brazilian malaria cases occur each year in this region, which has its own peculiar ecoepidemiological characteristics.

In the present study, natural infections were detected in anophelines collected at different locations within the Brazilian Amazon region from 1994 to 1998 . These data were interrelated with entomological parameters in order to demonstrate the role of each species in the transmission of malaria.

\section{MATERIAL AND METHODS}

Collections of anopheline adults for behavioral studies were made at 15 locations covering the Northern, Southern, Southeastern, Central and Eastern parts of the Brazilian Amazon region (Fig. 1). These areas were selected on the basis of their differences, such as the diversity and density of species. Some areas were residential, some were ecologically altered and others were still in a natural state. The mosquitoes, which were collected with human bait between 18:00 and 22:00 hours, were identified ${ }^{6,9,11}$ and maintained at $-70{ }^{\circ} \mathrm{C}$ until subsequent analysis. More detailed studies of biting activities require captures during periods of 12 or 24 hours. Collections were also made on domestic animals near dwellings. The studies for the identification of species of anophelines positive for Plasmodium vivax, $P$. falciparum and $P$. malariae were conducted from 1994 to 1998 and included mosquitoes caught at some of the 15 locations mentioned, plus the following sites: Barcelos, Fonte Boa, Maues, Caapiranga, Manacaparu, Labrea, Parintins, Airão, Coari, Urucú, Rodovia Manaus-Boa Vista (BR-174), Rodovia Cuiabá-Porto Velho (BR-364), and parts of Manaus known to have a high incidence of malaria cases. These anophelines were collected by technicians of INPA and the Fundação Nacional de Saúde, Regional do Amazonas. Collections made exclusively on cattle included 139 suspensions that were also tested for the three types of Plasmodium. Monoclonal antibodies against sporozoites CS were used ${ }^{2.27}$ in the immunoenzymatic tests (ELISA).

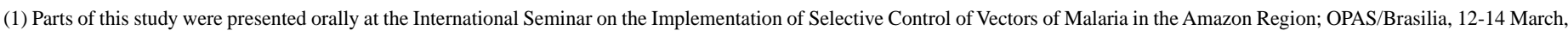
1996.

(2) Instituto Nacional de Pesquisas da Amazônia. Estrada do Aleixo 1756, Caixa Postal 478, 69083-000 Manaus, AM, Brasil. E-mail tadei@inpa.gov.br

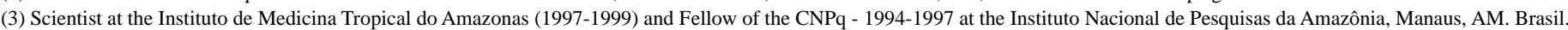

Correspondence to: Dr. Wanderli P. Tadei, Instituto Nacional de Pesquisas da Amazônia. Estrada do Aleixo 1756, Caixa Postal 478, 69083-000 Manaus, AM, Brasil. 
Some anophelines were individually tested but most of them were tested in groups of up to 10 selected according to species, location, date and hour of capture. For studies of species complexes, morphological characters, chromosomal ${ }^{12}$ and electrophoretic techniques ${ }^{21}$ as well as ribosomal $^{10}$ and mitochondrial DNA analyses ${ }^{13}$ were utilized on both immature and adult anophelines.

\section{RESULTS AND DISCUSSION}

In Brazil, 54 species of Anopheles are known and 33 of these occur in the Brazilian Amazon region ${ }^{7,22}$. Female anophelines that become infected with Plasmodium remain infected for life.

The total number of anophelines tested was 11,895 and Table 1 shows the number analyzed in each location identified in terms of species. The distribution of the percentage analyzed per year was as follows: $28 \%$ in 1994; $20 \%$ in 1995, 3\% in 1996, 30\% in 1997 and 10\% in 1998. Locations with the largest number of infected anophelines were: Itacoatiara $4.8 \%$, Lábrea $4.5 \%$, Iranduba 4\%, Parintins $3.7 \%$, Coari 2.9\%, and the BR174 Highway $2.8 \%$. The species tested for natural infections by means of ELISA totaled 4,106 suspensions containing up to 10 mosquitoes each. Assuming that at least one mosquito in each suspension would be infected with Plasmodium, the indexes of infection, shown in parentheses, varied among the species studied. In the subgenus Nyssorhynchus, the following species were found to be naturally infected by means of ELISA. Those positive for P. vivax were: An. triannulatus (1:27), An. mattogrossensis (1:51), An. nuneztovari (1:58), An. braziliensis (1:64), An. darlingi (1:77), An. mediopunctatus (1:77), and An. albitarsis (1:100). Species positive for $P$. falciparum were: An. triannulatus (1:130), An. albitarsis (1:136), An. nuneztovari (1:150), An. mattogrossensis (1:152), and An. darlingi (1:193). A single suspension of An. peryassui, containing only one mosquito, was positive for both of these Plasmodium species (Table 2). In the sample obtained from cattle, which consisted of 1,200 An.nuneztovari and 190 An. triannulatus, three suspensions of each species were found to be positive for $P$. malariae only; the indexes were 1:400 and 1:63, respectively. In other laboratories ${ }^{1,23}$, An. galvaoi, An. aquasalis and An. strode $i$ have been reported as positive for this species as determined by ELISA. Dissection of the salivary glands confirmed these findings.

Anopheles darlingi is the principal vector of malaria in Amazonia because it is highly anthropophilic ${ }^{1,7,22}$. Precipitin tests demonstrated that this mosquito has a preference for $\operatorname{man}^{7,8}$. The presence of this mosquito is always related to human cases and the mosquito can maintain endemic malaria even when present at a low density. Sporozoites are found at higher frequency in dissections of this species. Anopheles nuneztovari, allthough giving positive results with the ELISA test, seems to be incapable of causing outbreaks of malaria in the absence of An. darlingi. The same is true for the other species of mosquitoes that have been found infected.

The natural infection indexes obtained in this study for An. darlingi were lower than those of the other species. These results were caused by the collection method that did not take into account the feeding preferences of the anophelines. Since the collections were always made with human bait after 18:00 hours, An. darlingi predominated in the captures. This method reduced the possibility of catching the species that prefer to feed on peridomiciliary domestic animals (cattle, pigs, etc.).
Another factor that interfered with the index values was the high percentage of nulliparous females captured and tested in the sample of An. darlingi, which was obtained in the early hours. Since they were getting their first blood meal, these females were not infected and thus reduced the indexes. During the same time periods, females of other species prefer to feed on animals and therefore were not captured on human bait. However, including the females that prefer to feed on humans increased the index of infectivity since they were captured in areas where many malaria cases occur. Specimens of An. nuneztovari and An. triannulatus captured on cattle were negative for P. vivax and P. falciparum.

The other positive species, An. nuneztovari, An. triannulatus and An. albitarsis, of which more than 500 specimens were analyzed, might be considered as occasional vectors since they are found infected with Plasmodium only in areas where An. darlingi started an outbreak. The human cases registered by the regional offices of the FNS in Amazonia support this view.

Plasmodium malariae was only detected in An. nuneztovari and An. triannulatus captured on cattle.

When interpreting the importance of natural infection indexes in malaria transmission it is relevant to consider aspects of mosquito behavior, distribution and density, such as:

1. Behavior of the species

In natural areas

In altered areas

2. Feeding times

3. Endophilia and exophilia

4. Vertical distribution

5. Species complexes

\section{Behavior of the species}

Natural areas: The diversity and density of the species was variable. They were both low in the areas of the Uatumã and Pitinga rivers, before the construction of the Balbina hydroelectric dam (November 1983 to October 1986). This might have been caused by the acid waters in these rivers being low in nutrients. Only An. mediopunctatus and An. oswaldoi were present. In Rondonia, before the construction of the Samuel hydroelectric dam (September 1985 to October 1986), differences were found between the two borders of the Januari River. Differences were also found between the edge and the center of primary forest. On the right bank near the dike, we found five species at seven collection sites, and the index was 0.32 mosquitoes/man/hour. On the left bank, which had not been altered even though it was near the BR-364 highway, we found one more species (An. darlingi) and the index was 28 mosquitoes/ man/hour. The index was 3.13 mosquitoes/man/hour at the edge of the forest and 2.6 mosquitoes/man/hour within the primary forest. A different situation prevailed at Porteira Falls, Pará (October 1985 to August 1986). Along the Cachorro River An. darling $i$ was present and showed an index of 53 mosquitoes/man/hour and only a single specimen of An. oswaldoi was caught in this location. Therefore, the density of mosquitoes was high and the diversity of species was very low $^{23}$.

Altered areas: The studies were conducted in areas altered by constructions of hydroelectric dams, oil pipelines, highways and in towns where rapid and uncontrolled growth had occurred. 
Table 1

Localities, species and quantities of anophelines tested by ELISA, 1994-1998

\begin{tabular}{|c|c|c|c|c|c|c|c|c|c|c|c|c|}
\hline Localities & Total & darlingi & $\begin{array}{l}\text { nunez- } \\
\text { tovari }\end{array}$ & albitarsis & $\begin{array}{l}\text { triannu- } \\
\text { latus }\end{array}$ & $\begin{array}{c}\text { Mattogros- } \\
\text { sensis }\end{array}$ & $\begin{array}{c}\text { Brazili- } \\
\text { ensis }\end{array}$ & $\begin{array}{c}\text { medio- } \\
\text { punctatus }\end{array}$ & peryassui & oswaldoi & $\begin{array}{l}\text { puncti- } \\
\text { macula }\end{array}$ & others \\
\hline Manaus & 3876 & 1809 & 1469 & 239 & 295 & 2 & 57 & 4 & 1 & & & \\
\hline Novo Airão & 1761 & 1427 & 157 & 110 & 26 & 3 & 23 & 2 & 1 & 3 & & 9 \\
\hline Coari & 1349 & 1079 & 129 & 16 & 30 & 30 & & 64 & 1 & & & \\
\hline Highway BR-174 & 1105 & 127 & 864 & 23 & 87 & & 3 & 1 & & & & \\
\hline Boca de Acre & 707 & 68 & 1 & 626 & & 1 & 10 & & & & & 1 \\
\hline Urucu & 653 & 648 & 5 & & & & & & & & & \\
\hline Iranduba & 595 & 75 & 246 & 171 & 46 & 56 & & & 1 & & & \\
\hline Uatumá & 485 & & 145 & 329 & & 11 & & & & & & \\
\hline Itacoatiara & 376 & 60 & 110 & 190 & 2 & 13 & & 1 & & & & \\
\hline Humaitá & 359 & 235 & 38 & 39 & 15 & 25 & 6 & & & 1 & & \\
\hline Parintins & 148 & 11 & 16 & 110 & 10 & & & & & & 1 & \\
\hline Lábrea & 133 & 133 & & & & & & & & & & \\
\hline Manacapuru & 103 & 43 & 58 & & & 2 & & & & & & \\
\hline Caapiranga & 77 & 2 & 62 & 9 & 1 & 3 & & & & & & \\
\hline Highway BR-352 & 55 & 39 & 3 & 2 & 3 & 1 & 2 & 4 & & & & 1 \\
\hline Autazes & 28 & 7 & 4 & 17 & & & & & & & & \\
\hline Fonte Boa & 26 & & & & & & 26 & & & & & \\
\hline Maues & 24 & & & 23 & & & 1 & & & & & \\
\hline Manicoré & 16 & 16 & & & & & & & & & & \\
\hline São Paulo de Olivençã & 8 & & & & 3 & 5 & & & & & & \\
\hline Barcelos & 5 & 2 & & & & & & 1 & 2 & & & \\
\hline Highway AM-10, Km 4 & 5 & 3 & 1 & & 1 & & & & & & & \\
\hline TOTAL & 11895 & 5784 & 3308 & 1904 & 519 & 152 & 128 & 77 & 6 & 4 & 1 & 11 \\
\hline
\end{tabular}

Table 2

Anopheline species tested by ELISA, positive suspensions and infectivity indexes for Plasmodium vivax, P. falciparum, mixed infections and P. malariae in collections from Amazonas State, 1994 to 1998

\begin{tabular}{|c|c|c|c|c|c|c|c|}
\hline \multirow[b]{2}{*}{ Species } & \multirow[b]{2}{*}{$\begin{array}{c}\text { Number of } \\
\text { vectors tested }\end{array}$} & \multicolumn{2}{|c|}{ P. vivax } & \multicolumn{2}{|c|}{ P. falciparum } & \multirow{2}{*}{$\begin{array}{c}\begin{array}{c}P . v .+P . f \\
(\text { mixed })\end{array} \\
\begin{array}{c}\text { Positive } \\
\text { suspensions }\end{array}\end{array}$} & \multirow{2}{*}{$\begin{array}{c}\text { P. malariae } \\
\text { Positive } \\
\text { suspensions }\end{array}$} \\
\hline & & $\begin{array}{c}\text { Positive } \\
\text { suspensions }\end{array}$ & $\begin{array}{l}\text { Infectivity } \\
\text { Index }\end{array}$ & $\begin{array}{c}\text { Positive } \\
\text { suspensions }\end{array}$ & $\begin{array}{l}\text { Infectivity } \\
\text { Index }\end{array}$ & & \\
\hline An. darlingi & 5784 & 75 & $1: 77$ & 30 & $1: 193$ & 19 & \\
\hline An. nuneztovari & 3308 & 57 & $1: 58$ & 22 & $1: 150$ & 10 & 3 \\
\hline An. albitarsis & 1904 & 19 & $1: 100$ & 14 & $1: 136$ & 6 & \\
\hline An. triannulatus & 519 & 19 & $1: 27$ & 4 & $1: 130$ & 2 & 3 \\
\hline An. mattogrossensis & 152 & 3 & $1: 51$ & 1 & $1: 152$ & & \\
\hline An. braziliensis & 128 & 2 & $1: 64$ & & & 1 & \\
\hline An. mediopunctatus & 77 & 1 & $1: 77$ & & & & \\
\hline An. peryassui & 6 & & & & & $1(1: 6)$ & \\
\hline TOTAL & 11895 & 176 & - & 71 & - & 39 & 6 \\
\hline
\end{tabular}


Hydroelectric dams: Collections were made in the Amazonian region before, during and after the construction projects. It was seen in both Tucurui, Pará (December 1984 to May 1985) and in Balbina, Amazonas (November 1992 to November 1993) that some species of the Subgenus Nyssorhynchus such as An. nuneztovari and An. triannulatus colonized altered environments and became abundant or even dominant. On the other hand, some species such as An. intermedius were reduced in abundance or even disappeared. A third situation was found in Tucurui, Pará (August 1990 to October 1990) where An. argyritarsis was not found during the filling of the lake but appeared afterwards and then disappeared five years later. Anopheles braziliensis, which was absent in the area, was collected five years after the filling of the lake (1990). In an area Southeast of the filled lake it was possible to collect 462 mosquitoes/man/hour (calculated on the basis of 17 samples collected over a period of $90 \mathrm{hrs}$ ). Ninety percent of the mosquitoes in this collection were represented by An. nuneztovari.

At Balbina pre-construction collections (November 1983 to September 1987) demonstrated low densities of anophelines (0.51 mosquitoes/man/hour) at 62 collection sites. The diversity was also low and only two species were found. However, in farming areas the diversity and density were greater ( 7 species; 1.5 mosquitoes/man/hour at 13 collection sites). In studies made five years after the filling of the Balbina lake $^{14}(1992-1993)$ the diversity stood at 11 species and An. nuneztovari was dominant ${ }^{14}$. A general trend in most of the localities studied was the occurrence of low density in the middle of the forest both before and after the alteration. The increases in density were directly related to the formation of the lakes in cases of hydroelectric installations because of the growth of macrophytes, which form an excellent environment for the reproduction of anophelines.

Oil pipelines: In the case of environmental alterations caused by the construction of oil pipelines, mosquito control measures are usually employed. During the oil exploration of the Urucu River in the Amazonas by Petrobras (May 1996 to July 1996) control methods prevented anopheline populations from increasing and reduced contact between infected mosquitoes and man. These methods included treating the native population along the Urucu River to reduce the reservoir of Plasmodium parasites in that area; spraying the forest in the vicinity of the camps to lower the density of the infected mosquitoes; implementing individual control measures such as screening doors and windows and encouraging the use of mosquito nets.

Highways: At the beginning of the construction of the BR-174 Manaus-Boa Vista Highway (1965) An. darlingi coexisted with An. nuneztovari at densities of 19 mosquitoes/man/hour and 3.25 mosquitoes/

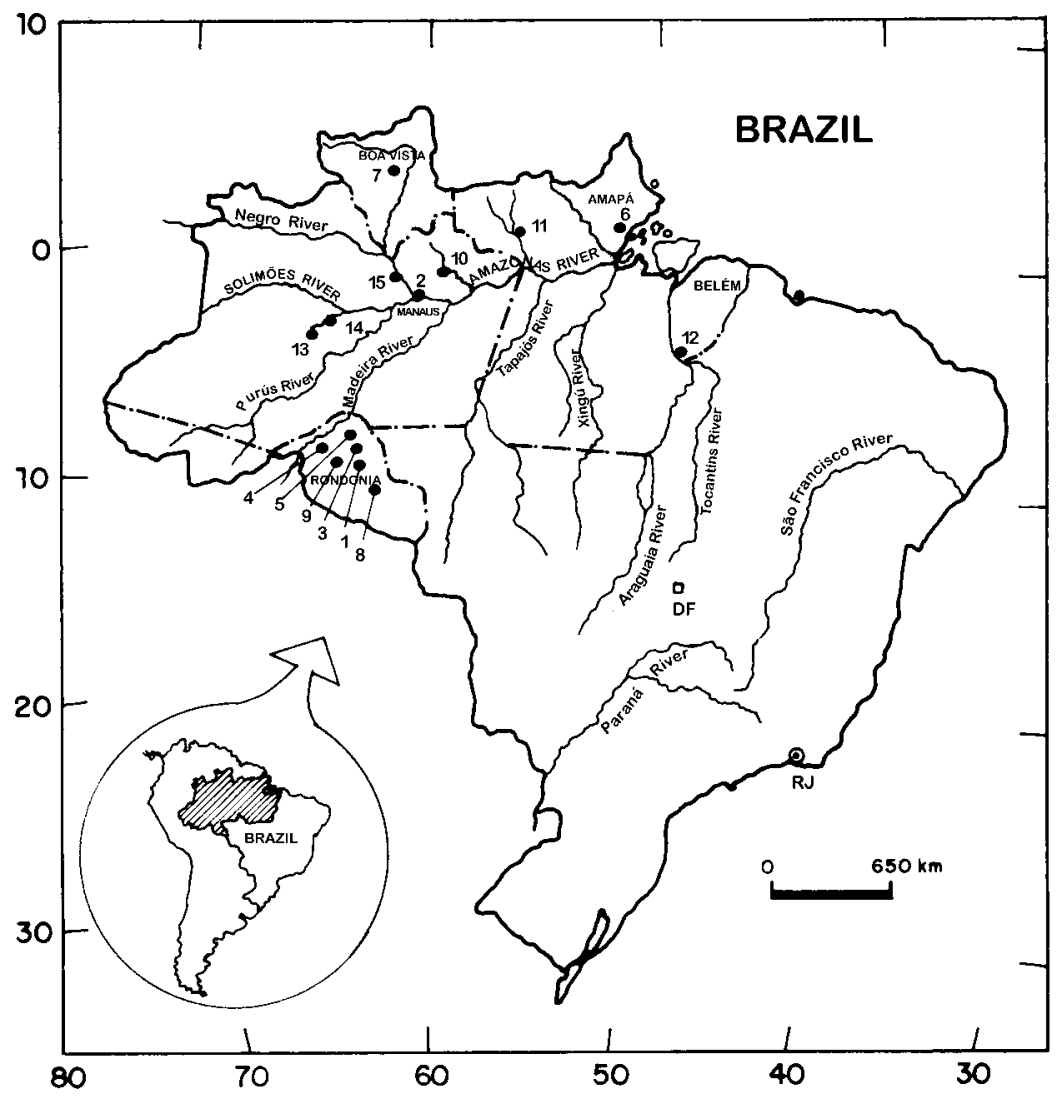

Fig. 1 - COLLECTION SITES

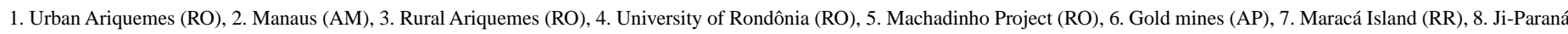

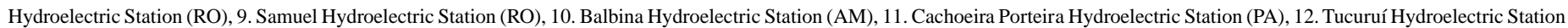
(PA), 13. Petroliferous Province - Petrobrás (AM), 14. Urucu River (AM), 15. Novo Airão (AM). 
man/hour, respectively. During subsequent observations in 1994 it was seen that the index for An. nuneztovari was 1.71 mosquitoes $/ \mathrm{man} /$ hour indoors and 6.42 mosquitoes/man/hour outdoors. On the other hand, the density of An. darlingi was 0.125 indoors and 0.449 outdoors, demonstrating a drop in the density of the principal vector of malaria. The cause of the reduction of An. darlingi might be that deforestation increased the distance between the forest edge and the human dwellings and also that the mosquito breeding sites were exposed to sunlight and the lack of sufficient shade made the habitat inappropriate for An. darlingi and favored the breeding of An. nuneztovari.

Another region affected by colonization and the construction of an access highway is the Municipality of Novo Airão (AM). This town is located on the right bank of the Rio Negro, $200 \mathrm{~km}$ from Manaus. Studies on malaria vectors were initiated in 1997 due to the surge in human malaria along this highway. The density and predominance of An. darlingi were demonstrated. Figure 2 shows the relation between the human cases and the seasonality of $A n$. darlingi but in order to interpret these data it is necessary to take into consideration the incubation time of the parasite in both mosquitoes and man.

Rapid growth of cities: In 1975, An. darlingi disappeared from the city of Manaus. In the years that followed, a rapid expansion extended the city into the surrounding forest, which re-established contact between man and the malarial vector, An. darlingi. In 1986, cases of malaria increased in Manaus and during the epidemic of 1993, 23,186 people contracted malaria in the city. The analysis of natural infection of $A n$. darlingi in the periphery of Manaus demonstrated indexes compatible with the large numbers of human malaria cases. As examples we can cite the Santa Etelvina sector with an infectivity index of 1 out of 6 An. darlingi infected (1:6), 1:46 in Cidade Nova and 1:50 in Chico Mendes.

\section{Hours of Hematophagia}

The anopheline species have a pattern of blood feeding that can be altered by:
- Presence in urban or rural area;

- Density of the anopheline species in relation to other species of culicids;

- Season of the year - rainy, dry or transition period;

- Distance between the forest and dwellings; and

- Presence of other hosts.

Presence in urban or rural areas: In the rural areas of Tucurui (Pará), BR-319 (Rondonia-Amazonas) and BR-174 ((Roraima-Amazonas) An. darlingi showed a pattern of continuous activity with a peak at nightfall and another at dawn, the latter being less intense. In the urban areas of Ariquemes (Rondonia) this anopheline was more numerous during the first period (18:00 - 19:00 hours). The other anophelines are only crepuscular with intense activity during the first hours of darkness. They may or may not have activity peaks at dawn. An. nuneztovari, An. oswaldoi, An. triannulatus, An. albitarsis and An. braziliensis showed very intense biting activity between 18:00 and 19:00 hours which ceased between 20:00 and 21:00 hrs. More detailed observations on An nuneztovari taken at 15 minute intervals demonstrated that the most intense activity peaks occurred between 19:00 and 19:30 hrs. These observations are comparable with those reported in other studies ${ }^{3.15,17}$.

Densities of anopheline species in relation to other species of culicids: The main feeding activities of anophelines usually occur from 18:00 to 21:00 hrs, but may be altered by the presence of large numbers of other culicids. In the region of the hydroelectric lake of Tucurui (Para), after the dam was filled, in the presence of many individuals and species of the genus Mansonia, it was found that the principal peak of anopheline activities was set forward from 18:00 to 19:00 hrs.

Season of the year - rainy, dry and transition periods: Human alterations in the environment as well as rainy and dry periods can cause times of hematophagia to vary. In farming regions with a high anopheline density and close relations to the breeding sites as in the periodically floodable lowlands of Roraima and Amapa, the pattern of biting activities is continuous from 18:00 to 6:00 hrs, and the dry and rainy seasons do

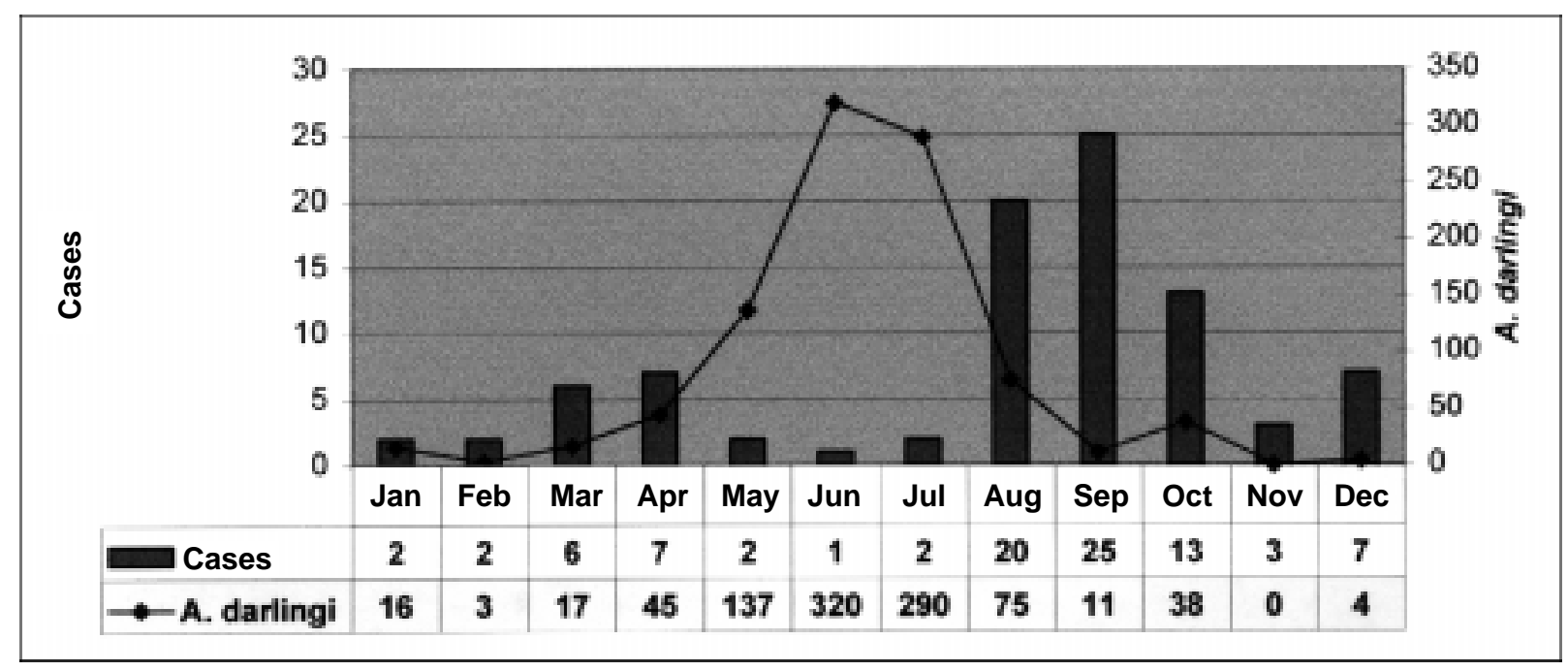

Fig. 2 - Seasonality of Anopheles darlingi and its relation with human malaria cases on Highway AM-352 Novo Airão (Amazonas), 1997. 
not greatly affect anopheline populations. During the rainy period (December to May) the anopheline densities increase because of the large number of temporary breeding sites. At such times biting activities can go on all night. In summer (September to November) because there are fewer breeding sites the mosquito density drops. Table 3 shows a drop in the density of An. darlingi during the four years of collection and a relatively abrupt increase in other species such as An. galvaoi, An. peryasssui and An. strodei. For An. galvaoi and An. peryassui, which showed a preference for cattle during the transition period (June to August when there are cool spells), biting activity became intense during the first hours of darkness.

Distance between the forest and dwellings: During the drier months from September to November the anopheline breeding sites are frequently farther from human dwellings and mosquito density is low. Studies were made in Rondonia (Ariquemes) from August 1985 to November 1988 in settlements along the highways. The houses are constructed in an open area between the highway and the primary forest. It was observed that An. darlingi was active nocturnally and diurnally and returned to the forest after feeding. As deforestation proceeded and the dwellings were located farther from the forest An. darling $i$ became entirely nocturnal and its diurnal activity ceased. It is estimated that between 3 and 5 years are required for the establishment of a stable cycle.

Presence of other hosts: In rural Ariquemes, collections of anophelines were made on cattle, pigs, man and on vegetation near dwellings from August 1985 to November 1988. These collections were made simultaneously in order to evaluate levels of antropophilia and zoophilia. Anopheles strodei, An. galvaoi and An. peryassui were highly zoophilic, showing a preference for cattle and pigs and the incidence of these species was higher in cattle. Anopheles darlingi showed a preference for man and $59 \%$ of the specimens were collected feeding on man or resting on nearby vegetation ${ }^{23}$.

\section{Endophilia and Exophilia}

Observations made during the forties showed that An. darlingi was the principal vector of malaria indoors during the night ${ }^{7}$. In one location in rural Ariquemes (Rondonia) during the Burarero Project, 1,974 anophelines were collected and only $18 \%$ were found inside the dwellings; of these $99 \%$ were An. darling $i$ and other species predominated outdoors. The highest percentage of endophilia of An. darlingi was observed in one of the colonies of the Machadinho Project in Rondonia (October 1986 to December 1987). In that location 415 specimens were collected at 37 sites and $32 \%$ of these were collected indoors. Along highway BR-364, $26 \%$ of a total of 1,546 anophelines were captured indoors. In the region of Tucurui in colonies situated on the banks of the lake the endophilia was $40 \%$ among 3,006 anophelines captured. Among these An. nuneztovari predominated and represented $85 \%$ of the total captured indoors. In the residential areas of the hydroelectric stations of Samuel, Balbina and Tucurui the houses are completely screened and therefore only $0.6 \%$ of 500 specimens of An. darlingi were captured indoors. Endophilia tends to diminish as a result of changes in the habits of people and possibly because of adaptations in the behavior of anophelines brought on by the massive use of insecticides ${ }^{24}$.

\section{Vertical Distribution}

Studies on feeding behavior conducted in Ariquemes (Rondonia) between May and August 1986 demonstrated that these mosquitoes enter the houses through low cracks. They did not rest on interior walls that had been sprayed with DDT. Around the houses they rested on bushes

Table 3

Densities of four anopheline species sampled over a four year period during the rainy, dry and transition seasons

\begin{tabular}{|c|c|c|c|c|c|c|c|c|c|c|}
\hline \multirow[b]{2}{*}{ Year 1} & \multicolumn{2}{|c|}{ An. darlingi } & \multicolumn{2}{|c|}{ An. strodei } & \multicolumn{2}{|c|}{ An. galvaoi } & \multicolumn{2}{|c|}{ An. peryassui } & \multicolumn{2}{|c|}{ TOTALS } \\
\hline & & & & & & & & & 3118 & \\
\hline Transition & 419 & $(13 \%)$ & 1 & $(>1 \%)$ & 2 & $(>1 \%)$ & 0 & & 422 & $(13 \%)$ \\
\hline Dry & 153 & $(5 \%)$ & 45 & $(1 \%)$ & 404 & $(13 \%)$ & 78 & $(3 \%)$ & 680 & $(22 \%)$ \\
\hline Rainy & 93 & $(3 \%)$ & 360 & $(11 \%)$ & 1450 & $(46 \%)$ & 113 & $(4 \%)$ & 2016 & $(65 \%)$ \\
\hline Year 2 & & & & & & & & & 5209 & \\
\hline Transition & 29 & $(>1 \%)$ & 285 & $(5 \%)$ & 812 & $(16 \%)$ & 391 & $(8 \%)$ & 1517 & $(29 \%)$ \\
\hline Dry & 15 & $(>1 \%)$ & 111 & $(2 \%)$ & 449 & $(9 \%)$ & 828 & $(16 \%)$ & 1403 & $(27 \%)$ \\
\hline Rainy & 6 & $(>1 \%)$ & 270 & $(5 \%)$ & 1877 & $(36 \%)$ & 136 & $(3 \%)$ & 2289 & $(44 \%)$ \\
\hline Year 3 & & & & & & & & & 2456 & \\
\hline Transition & 26 & $(1 \%)$ & 28 & $(1 \%)$ & 1168 & $(48 \%)$ & 122 & $(5 \%)$ & 1344 & $(55 \%)$ \\
\hline Dry & & $(>1 \%)$ & 14 & $(>1 \%)$ & 619 & $(25 \%)$ & 58 & $(2 \%)$ & 704 & $(29 \%)$ \\
\hline Rainy & 13 & $(>1 \%)$ & 4 & $(>1 \%)$ & 322 & $(13 \%)$ & 69 & $(3 \%)$ & 408 & $(17 \%)$ \\
\hline Year 4 & & & & & & & & & 1478 & \\
\hline Transition & 122 & $(8 \%)$ & 16 & $(1 \%)$ & 550 & $(37 \%)$ & 90 & $(6 \%)$ & 778 & $(53 \%)$ \\
\hline Dry & 198 & $(13 \%)$ & 3 & $(>1 \%)$ & 442 & $(30 \%)$ & 57 & $(4 \%)$ & 700 & $(47 \%)$ \\
\hline TOTALS & 1087 & $(9 \%)$ & 1137 & $(9 \%)$ & 8095 & $(66 \%)$ & 1942 & $(16 \%)$ & 12261 & \\
\hline
\end{tabular}


about one meter above the ground, with consequent improbable contact with residual insecticide ${ }^{23}$. Observations made in 1980 in Northern Amazonia (BR-174) also showed that anophelines were avoiding contact with residual insecticide ${ }^{3}$. Both of these are example of an adaptation to environmental conditions in which the mosquitoes can enter a house, take a blood meal and leave without coming into contact with an insecticide.

\section{Species complexes}

The description of cryptic species complexes of the genus Anopheles is contributing to the identification of related species, permitting the recognition of those involved in the transmission of malaria. In Amazonia at present An. darlingi, An. albitarsis and An. nuneztovari are of special interest.

Population studies on An. darlingi in terms of behavioral patterns, data on chromosomes, alloenzymes and cuticular hydrocarbons have so far not shown sufficient differences to suggest that there are subpopulations of this species. A high degree of variability can be seen in this species giving it sufficient adaptive plasticity to exploit the different habitats of its extensive geographic distribution. The geographic differences apparently do not interfere with its capacity as a vector ${ }^{16,17,19}$.

Morphological and alloenzymatic studies of An. albitarsis made it possible to distinguish a population that was described as An. deaneorum Rosa-Freitas, 1989 belonging to the An. albitarsis complex ${ }^{18,25,26}$. On the basis of the wing characters, alloenzymes and mitochondrial DNA, a complex of species was proposed for An. albitarsis in Brazil. At least two species can be identified by morphological characters, namely $A n$. deaneorum and An. marajoara. The latter species contains three cryptic forms with the following geographic distribution: Marajo Island in Pará State, Iguape in São Paulo and Costa Marques in Rondonia State.

Samples from Brazil, Venezuela, Paraguay and Argentina where analyzed with RAPD-PCR markers (Random amplified polymorphic DNA and Polymerase Chain reaction) in order to identify other species of the An. albitarsis complex. Based on the results of these experiments, the following species and their geographic distribution were designated:

Species A: An. albitarsis sensu stricto occurring in Southern Brazil, Paraguay and Argentina;

Species B: To be described, occurring along the Brazilian coast from Pará to Southern Brazil and at some localities in Paraguay.

Species C: An. marajoara occurring in Northern Venezuela and in Central, Western, and Southeastern Rondonia, Brazil.

Species D: An. deaneorum occurring in Rondonia and localities in Southeastern Brazil, Paraguay and Argentina.

Anopheles nuneztovari is a neotropical species playing an important role in the transmission of human malaria. It occurs mainly in countries of Northern South America and Eastern Panama. Studies on the differentiation of the species show interesting aspects related to chromosomes and molecular markers. Data on chromosomal polymorphism permit us to propose the occurrence of three cytotypes.

Cytotype A: Carries the basic pattern, is distributed throughout the Brazilian Amazon and has a fixed inversion on chromosome X.
Cytotype B: Carries an inversion on chromosome II (2La) and is distributed from Venezuela to the Southeast of the Andes Mountain.

Cytotype C: Carries a complex of inversions (2Lc and 2Ld) included in $2 \mathrm{Lb}$ and a well defined chromocenter and is distributed in Western Colombia and Venezuela.

Studies of ribosomal and mitochondrial DNA in populations of An. nuneztovari from Venezuela, Colombia, Brazil, Surinam and Bolivia have not shown sufficient differences to suggest a complex of species ${ }^{4.5,10}$. Data on alloenzymes of populations of An. albitarsis from the Brazilian Amazon and from Colombia revealed a high level of genetic divergence. The genetic difference found was 0.047 to 0.148 , which is similar to that found among members of anopheline species complexes ${ }^{20}$.

\section{CONCLUSIONS}

Amazonian ecosystems are very complex and habitats are so diverse as to make generalizations difficult. Human interventions also vary and cause different types of environmental alterations. In the cities of Manaus and Novo Airão, the densities and infectivity indexes of anophelines are low due to control methods used against adult mosquitoes. However, only a few An. darlingi are needed to maintain malaria circulating in a population because this vector is very efficient in transmitting both $P$. vivax and $P$. falciparum. In ELISA tests, An. nuneztovari was found to be positive for $P$. vivax and P.falciparum. However, its efficiency as a vector in Amazonas State was not demonstrated because human cases were only found in areas infested with An. darlingi. Plasmodium malariae was found in An. nuneztovari and An. triannulatus collected on cattle along the BR-174 Highway. The malaria vectors adapt to environmental alterations. They can change their behavior, host and feeding habits, thereby showing environmental plasticity. Thus, it is necessary to study the conditions of each area, as well as the habits and customs of the community before deciding on the control strategies to be used.

\section{RESUMO}

\section{Anopheles do subgênero Nyssorhynchus, vetores da Malária na Amazônia Brasileira}

Várias espécies de Anopheles (Nyssorhynchus) foram estudadas na Amazônia a fim de se determinar sua importância na transmissão da malária. Das 33 espécies de Anopheles de ocorrência conhecida na Amazônia, apenas 8 foram encontradas infectadas por Plasmodium. O principal vetor, An. darlingi, é antropofílico com um ciclo contínuo de atividade que dura a noite inteira mas que tem picos ao anoitecer e ao amanhecer. As diferentes espécies desse subgênero variaram tanto em diversidade como em densidade nas áreas de coleta. A população de anofelinos apresentou tendências de menor densidade e diversidade em florestas virgens do que em áreas que sofreram intervenção humana.

Essas espécies (Nyssorhynchus) são peridomiciliares entrando nas casas para se alimentar de sangue. De imediato retiram-se e pousam-se novamente na vegetação próxima.

Anopheles nuneztovari provou ser zoofílico, crepuscular e peridomiciliar. Esses hábitos podem mudar dependendo de uma série de fatores externos, especialmente aqueles relacionados com as atividades 
humanas. Os índices de infecção mostrados foram altos. No entanto os registros não mostram que surtos são desencadeados senão quando os casos de malária provocados pelo An. darlingi são detectados.

Há possibilidade de que existam espécies crípticas na área, são estudadas com referência a An. darlingi, An. albitarsis e An. nuneztovari. Nessas circunstâncias, os resultados atuais, não sugerem a existência de subpopulações de An. darlingi na Amazônia brasileira.

\section{ACKNOWLEDGEMENTS}

The authors are grateful to PPDG/G7-FINEP, CNPq, SUDAM, PETROBRÁS and ELETRONORTE for financial support. Personnel of the Fundação Nacional de Saúde - Regional do Amazonas aided in the capture of anophelines in several localities.

\section{REFERENCES}

1. ARRUDA, M.; CARVALHO, M.B.; NUSSENZWEIG, R.S.; MARARIC, M. \& FERREIRA, A. W. - Potential vectors of malaria and their different susceptibility to Plasmodium falciparum and Plasmodium vivax in northern Brazil identified by immunoassay. Amer. J. trop. Med. Hyg., 35: 873-881, 1986.

2. BRANQUINHO, M.S.; LAGOS, C.B.T.; ROCHA, R.M. et al. - Anophelines in the state of Acre, Brazil, infected with Plasmodium falciparum, $P$. vivax, the variant VK247 and P. malariae. Trans. roy. Soc. trop. Med. Hyg., 87: 391-394, 1993.

3. CHARLWOOD, J.D. \& HAYES, J. - Variações geográficas no ciclo de picada de Anopheles darlingi Root no Brasil. Acta amaz. (Manaus), 8: 601-603, 1978.

4. CONN, J. - A genetic study of the malaria vector Anopheles nuneztovari from western Venezuela. J. Amer. Mosq. contr. Ass., 6: 400-405, 1990.

5. CONN, J.; PUERTA, Y.R. \& SEAWRIGHT, J.A. - A new cytotype of Anopheles nuneztovari from western Venezuela and Colombia. J. Amer. Mosq. contr. Ass., 9: 294-301, 1993.

6. CONSOLI, R.A.G.B. \& LOURENÇO DE OLIVEIRA, R. - Principais mosquitos de importância sanitária no Brasil. Rio de Janeiro, Fiocruz, 1994.

7. DEANE, L.M. - Malaria vectors in Brazil. Mem. Inst. Oswaldo Cruz, 81: 5-14, 1986.

8. DEANE, L.M. - Malaria studies and control in Brazil. Amer. J. trop. Med. Hyg., 38: 223-230, 1988 .

9. FORATTINI, O.P. - Entomologia médica. Diptera Anophelini. São Paulo, Faculdade de Higiene e Saúde Pública, 1962.

10. FRITZ, G.N.; CONN, J.; COCKBURN, A. \& SEAWRIGHT, J. - Sequence analysis of the ribosomal DNA internal transcribed spacer 2 from populations of A. nuneztovari (Diptera; Culicidae). Molec. Biol. Evol., 11: 406-416, 1994.

11. GORHAM, J.R.; STOJANOVICH, C.J. \& SCOTT, H.G. - Clave ilustrada para los anofelinos de Sudamerica Oriental. Atlanta, Communicable Disease Center, United States Public Health Service, 1967.

12. KITZMILLER, J.B.; KREUTZER, R.D. \& TALLAFERRO, E. - Chromosomal differences in populations of Anopheles nuneztovari. Bull. Wld. Hlth. Org., 48: 435-445, 1973.

13. NARANG, S.K.; KLEIN, T.A.; PERERA, O.P.; LIMA, J.B. \& TANG, A.T. - Genetic evidence for the existence of cryptic species in the Anopheles albitarsis complex in Brazil: allozymes and mitochondrial DNA restriction fragment length polymorphisms. Biochem. Genet., 31: 97-112, 1993.
14. OSORIO, Q.L.; DUTARY-THATCHER, B. \& TADEI, W.P. - Biologia de anofelinos amazônicos. XXI. Ocorrência de espécies de Anopheles e outros culicídeos na área de influência da Hidrelétrica de Balbina, cinco anos após o enchimento do reservatório. Acta amaz. (Manaus), 26: 281-296, 1996.

15. PANDAI, R.S. - Anopheles nuneztovari and malaria transmission in Surinam. Mosquito News, 37: 728-737, 1977.

16. ROSA-FREITAS-SIBAJEV, M.G.; CONN, J.; MITCHELL, S.E. et al. - Mitochondrial, DNA and morphological analyses of Anopheles darlingi populations from Brazil (Diptera: Culicidae). Mosquito System., 27: 78-99, 1995.

17. ROSA-FREITAS, M.G.; BOORMFIELD, G.; PRIESTMAN, A. et al. - Cuticular hydrocarbons, isozymes and behaviour of three populations of Anopheles darlingi from Brazil. J. Amer. Mosq. contr. Ass., 8: 357-366, 1992.

18. ROSA-FREITAS, M.G.; DEANE, L.M. \& MOMEN, H. - A morphological, isoenzymatic and behavioural study on ten populations of Anopheles (Nyssorhynchus) albitarsis Lynch-Arribalzaga, 1878 (Diptera: Culicidae) including from the type-locationBaradero, Argentina. Mem. Inst. Oswaldo Cruz, 85: 275-289, 1990.

19. SANTOS, J.M.M. - Diferenciação genética em populações de Anopheles. In: Encontro de Genética do Nordeste, Regional Bahia, 13., Feira de Santana, 1998. Feira de Santana, Universidade Estadual de Feira de Santana; Sociedade Brasileira de Genética, 1998. Anais. p. 179-184.

20. SCARPASSA, V.M.; TADEI, W.P. \& SUAREZ, M.F. - Allozymes differentiation among allopatric populations of Anopheles nuneztovari Gabaldón, 1940 (Diptera: Culicidae). Braz. J. Genet., 19: 265-269, 1996.

21. STEINER, W.W.M. \& JOSLYN, D.J. - Electrophoretic techniques for the genetic study of mosquitoes. Mosquito News, 39: 35-54, 1979.

22. TADEI, W.P.; DUTARY THATCHER, B.; SANTOS, J.M.M. et al. - Ecologic observations on anopheline vectors of malaria in the Brazilian Amazon. Amer. J. trop. Med. Hyg, 59: 325-335, 1998.

23. TADEI, W.P.; SANTOS. J.M.M.; SCARPASSA, V.M. \& RODRIGUES, I.B. Incidência, distribuição e aspectos ecológicos de espécies de Anopheles (Diptera: Culicidae), em regiões naturais e sob impacto ambiental da Amazônia Brasileira. In: FERREIRA, E.J.G.; SANTOS, G.M.; LEÃO, E.L.M. \& OLIVEIRA, L.A., ed. Bases científicas para estratégias de preservação e desenvolvimento da Amazônia. Manaus, Instituto Nacional de Pesquisas da Amazônia, 1993. p. 167-196.

24. TADEI, W.P. \& CORREIA, J.M. - Biologia de anofelinos amazônicos. IV. Observações sobre a atividade de picar de Anopheles nuneztovari Gabaldón (Diptera: Culicidae). Acta Amaz. (Manaus), 12: 71-74, 1982.

25. WILKERSON, R.C.; PERSONS, T.J.; KLEIN, T.A. \& GAFFIGAN, T.V. - Discovery by RAPD-PCR of cryptic species belonging to the Anopheles (Nyssorrynchus) albitarsis complex from Paraguay, Argentina and Brazil (Diptera: Culicidae). J. med. Ent., 32: 697-704, 1995a.

26. WILKERSON, R.C.; GAFFIGAN, T.V. \& LIMA, J.B. - Identification of species related to Anopheles (Nyssorhynchus) albitarsis by random amplified polymorphic DNApolymerase chain reaction (Diptera: Culicidae). Mem. Inst. Oswaldo Cruz, 90: 721-732, 1995b.

27. WIRTZ, R.A; SATTABONKGKOT, J.; HALL, T.; BURKOT, T.R. \& ROSENBERG. R. - Development and evaluation of an enzyme-linked immunosorbent assay for Plasmodium vivax-VK247 sporozoites. J. med. Ent., 29: 854-857, 1992.

Received: 06 July 1999

Accepted: 02 March 2000 